\title{
Author/Title Index Vol. 11 (1991)
}

The numbers in brackets give the issue in which the article can be found.

Adams, R., Issues in decision support in libraries

(1) $43-49$

Babington, A., PC based graphics standards and interfaces

$(5,6) 307-313$

Blair, G.S., see Williams, N.

Booth, A., The implementation of integrated information systems

(4) $203-211$

Cawkell, A.E., Editorial: Information management in business

(1) $1-2$

Cawkell, A.E., Lethally innocuous visual display units

(1) $33-41$

Cawkell, A.E., Editorial: Image Processing

$(5,6) 263-264$

Chatterton, P.F., Multimedia computing in the retail industry

$(5,6) 337-344$

Choo, C.W., Executive Information Systems: an application scenario in retail banking

(4) $213-224$

Clever, E.C. and D.P. Dillard, What do CD-ROM users really need?

$(2,3) 141-153$

Coles, E., An example of integrated systems for the provision of library and information services

(4) $237-246$

Crookes, D., see Philip, G.

Crowther, P.J., see O'Docherty, M.H.

Daskalakis, C.N., see O'Docherty, M.H.

Davies, N., see Williams, N.

Dillard, D.P., see Clever, E.C.

Dos Santos, B.L., V.S. Mookerjee and G. Salvendy, A conceptual model for optimizing the cost of knowledge acquisition

Dunn, R.G., The path of information technology: is it paved with good inventions?

Elias, A.W., Editorial: The information industry press-impressions

(1) $9-21$

(4) $225-235$

Ford, D.M., see Higgins, C.A.

Glacel, B.P., An organizational attitude toward quality

$(2,3) 103$

Goble, C.A., see O'Docherty, M.H.

Goodrich, B.A., Public relations: a marketing tool

Granick, L., Assuring the quality of information dissemination: responsibilities of database producers

Higgins, C.A. and D.M. Ford, Note-pad computers and the concept of Electronic Paper

$(2,3) 105-110$

$(2,3) 137-140$

$(2,3) 117-136$

Hodson, S., Multimedia: revolution or evolution?

(4) $179-192$

Ireton, M.A., see O'Docherty, M.H.

Juhasz, Z., see Philip, G.

Kalseth, K., Strategic uses of information-challenges for the information services department

Kalseth, K., Business information strategy-the strategic use of information and knowledge

Langerman, S., Marketing a database in the social sciences; description of an experience and its results

Logan, A., Paperless office: fact or fiction?

(5,6) 301-305

Lyons, P., The role of copyright in a digital environment

(1) $63-71$

$(2,3)$ 155-164

(1) $3-8$

(4) 193-201

$(2,3)$ 111-116

0167-5265/92/\$05.00 @ 1992 - Elsevier Science Publishers B.V. All rights reserved 
Mookerjee, V.S., see Dos Santos, B.L.

Oakley, J., see O'Docherty, M.H.

O'Docherty, M.H., C.N. Daskalakis, P.J. Crowther, C.A. Goble, M.A. Ireton, J. Oakley and C.S. Xydeas, The design and implementation of a multimedia information system with automatic content retrieval

Oppenheim, C., Legal issues for information professionals: some recent developments

(1) $73-85$

Ortasse, M., The role of information in modern industrial companies

(1) $51-54$

Philip, G., D. Crookes and Z. Juhasz, An image database on a parallel processing network

Prickett, D., Gateways and networks-new highways and traffic jams

Salvendy, G., see Dos Santos, B.L.

Stone, R.J., Virtual Reality and Cyberspace: from science fiction to science fact

Weiske, C., Chemistry information in West Germany

(1) $55-61$

Williams, N., G.S. Blair and N. Davies, Distributed multimedia computing: an assessment of the state of the art

Xydeas, C.S., see O'Docherty, M.H. 